\title{
THE REACTIONS AND RESISTANCE OF FISHES IN THEIR NATURAL ENVIRONMENT TO SALTS
}

\author{
MORRIS M. WELLS
}

THREE FIGURES

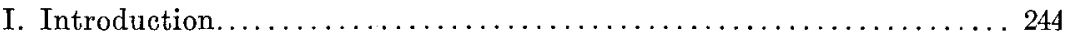

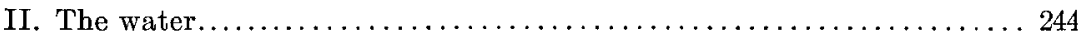

III. Methods and apparatus................................... 245

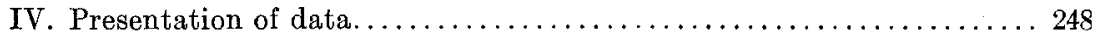

A. Reaction experiments............................. 248

1. Reaction to chlorides............................. 248

a. Ammonium chloride........................ 248

b. Potassium chloride....................... 248

c. Sodium chloride........................... 249

d. Calcium chloride.......................... 249

e. Magnesium chloride......................... 250

2. Reaction to nitrates............................ 250

a. Ammonium nitrate........................ 250

b. Potassium nitrate.......................... 251

c. Sodium nitrate........................... 251

d. Calcium nitrate........................... 252

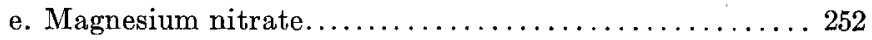

3. Reaction to sulphates....................... 253

a. Ammonium sulphate...................... 253

b. Potassium sulphate..................... 253

c. Sodium sulphate....................... 253

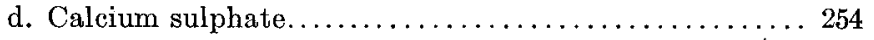

e. Magnesium sulphate...................... 254

4. Conclusions from reaction experiments . . . . . . . . 255

B. Antagonising salts and the reaction of fishes............... 255

C. Physiological states and the reactions of fishes............. 260

1. Reaction of starved fishes to $\mathrm{CaCl}_{2} \ldots \ldots \ldots \ldots \ldots \ldots \ldots 262$

2. Reaction of starved fishes to low oxygen.............. 264

D. Acclimatization and the reaction of fishes................. 265

E. Resistance of fishes to salts............................ 267

1. Resistance to ammonium salts......................... 267

2. Resistance to potassium salts................... 271

3. Resistance to sodium salts...................... 272

4. Resistance to calcium and magnesium salts........... 273

V. General discussion. . . . . . . . . . . . . . . . . . . . . . . . . . . . 274

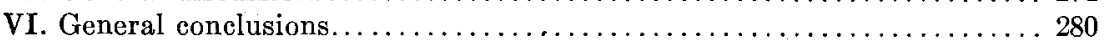

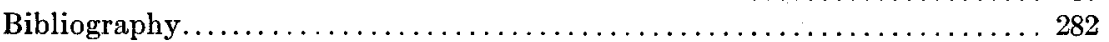




\section{INTRODUCTION}

In a previous paper (Wells ' 15 a) the reactions and resistance of fresh water fishes to alkalinity, acidity and neutrality were discussed upon the basis of experimental evidence which seemed to indicate that the chemical reaction of the water (i.e., acid, neutral or alkaline) in which the fishes live, is a matter of considerable importance to fresh water fishes and probably to marine fishes also (Shelford and Powers '15). In the present paper a large number of experiments bearing upon the reactions and resistance of fresh water fishes to salts is presented. Practically no previous work has been published upon the reactions of fishes to salts and the main part of the data presented here has to do with this phase of the subject. Some interesting relations between acidity and resistance to salts are also presented. This latter phase of the subject has been worked out in a preliminary way only; the more definite relations are left for further investigation.

The present investigation was begun at the suggestion of Prof. V. E. Shelford and was carried on at the University of Chicago during the years 1912 and 1913. In the fall of 1914 operations were transferred to the University of Illinois as the author accompanied Dr. Shelford in his transfer to that place.

\section{THE WATER}

The differences in the water of the two institutions have been discussed in the first paper of the series (Wells, l. c.). The chief differences are the following: The water at Chicago comes from Lake Michigan; as it flows from the tap in the laboratory, it is slightly acid with carbon dioxide (2-3 cc. per liter), is supersaturated with $\mathrm{O}_{2}$ (8-10 cc. per liter), contains 32 cc. per liter of half-bound $\mathrm{CO}_{2}$ (bicarbonates) and a proportionate amount of other salts. The water at the University of Illinois comes from deep wells. As it flows from the tap it is strongly acid (18 cc. $\mathrm{CO}_{2}$ per liter $)$, contains practically no $\mathrm{O}_{2}(0.12$ cc. per liter $)$ and the half-bound $\mathrm{CO}_{2}$ equals $101 \mathrm{cc}$. per liter; other salts are in proportion. Aeration brings the two waters to more nearly 
the same condition and fishes can live in either after the proper amount of aeration. Too much aeration causes the Illinois water to become alkaline to phenolphthalein and fresh water fishes cannot live in such water.

\section{METHODS AND APPARATUS}

The reaction experiments have been performed in the gradient tank used in the acid gradient experiments (Wells '15 a, fig. 1, p. 223).

The salts used have been, the chlorides, nitrates and sulphates, of ammonium, potassium, sodium, calcium and magnesium. In presenting the results of the reaction experiments the salts will be grouped with reference to the anion, as the similarities in behavior, in the different salt gradients, make this a rather natural division. They will also be taken up in the order of increasing toxicity of this ion as worked out by Lillie ('10) and others. Thus the order of consideration will be, chlorides, nitrates, sulphates. In considering the resistance experiments, on the other hand, the salts will be grouped according to the kation. In the gradient experiments the concentration of salt introduced at the salt end has been in nearly all cases $0.01 \mathrm{~N}$. In a few experiments the concentration was made $0.02 \mathrm{~N}$ or even higher in an attempt to drive the fishes out of the salt end, to which they were giving a positive reaction. These experiments will be cited as they come up.

The gradient in the salt experiments was obtained as follows: Tap water was set to flowing into one end of the tank at the rate of $500 \mathrm{cc}$. per minute, and into the other end at the rate of 400 cc. per minute. A $0.05 \mathrm{~N}$ solution of the salt was made up with tap water and run into the flow at the $400 \mathrm{cc}$. end at the rate of $100 \mathrm{cc}$. per minute. This made the volume of the flow at the two ends equal. The salt solution was mixed with the tap water, in a mixing bottle, outside the experimental tank. From the mixing bottle a single outlet led to the experimental tank. At first the gradients were tested before and after each experiment. Later, after a very careful study of the gradient 
had been made at Chicago, by determining the conductivity of the water at various points in the tank, tests were no longer made. Thus the actual concentrations existing throughout the tank have not been determined in each experiment but the study that was made indicated very clearly that under the given conditions this concentration is almost constant for a given salt. Thus there always exists a gradient of the dissolved salt, between the two ends of the tank. The presence of this gradient is shown by the reactions of the fishes as well as by the conductivities and titrations. That the gradient is not perfect is to be expected; its peculiarities were brought out in the study which

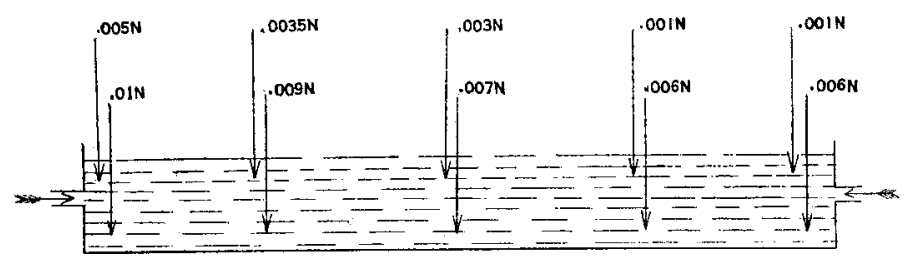

Fig. 1 Longitudinal section through the gradient tank. The figures indicate the concentrations of the salt at the depths indicated by the arrows. These concentrations were ascertained by determining the conductivity of samples taken from the different parts of the tank; in determining the gradient 7 samples along any given level were taken; only five are shown in the figure.

was made by means of the conductivity method. Figure 1 shows the gradient as it existed after the flows at the ends had been running for some time.

It will be noted from figure 1 that at any given level there is a gradient of salt from end to end of the tank. The concentration at the bottom of the tank was much higher than that near the surface of the water, and thus the fishes at times reacted to the vertical gradient, which was much sharper than the horizontal one. This reaction to the vertical gradient did not interfere greatly with the experiments, however, because the fishes tend to swim back and forth in the tank at whatever level they may be. Furthermore, most of the fishes worked with, remained near the bottom for a large proportion of the time. A further, 
point brought out by the conductivity measurements was that the water, after flowing in at the ends of the tank for 15 minutes or less, often showed a piling up of the salt at a point about two-thirds of the way to the tap water end, i.e., a little past the middle. This piling up was brought out graphically by the use of colored salt solutions, which showed a more intense color at this point for a short time. Later the deepening in color disappeared, and tests showed the gradient to be continuous from one end of the tank to the other.

Before the fact of the piling up of the salt was discovered, it was noted that the fishes often gave a negative reaction to this part of the tank. With the demonstration of the increased salt concentration at the point in question, and the fact that the increase disappeared after the flow at the ends had been on for about 30 minutes, most of the experiments were delayed until sufficient time had elapsed for the adjustment to take place; any marked reaction of the fishes at the point of higher concentration, was noted and recorded. That the gradient as shown in figure 1 is a typical gradient is supported by the fact that Shelford and Powers ('15) figure a similar gradient which they obtained between sea-water and fresh water, in their work with marine fishes. In the following gradient experiments, attention should be called to the fact that the reactions whether positive or negative are seldom 100 per cent reactions. In other words, the fishes are nearly always positive to some concentration of the salt in question. It seems that for most fresh water fishes there exists an optimum salt concentration somewhere between a $0.01 \mathrm{~N}$ and that of the tap water. This fact is brought out in the experiments with a majority of the salts.

The species of fishes used principally have been the black bullhead (Ameiurus melas), blue gills (Lepomis pallidus), rock bass (Amblopites rupestris), green spotted sun fish (Lepomis cyanellus), white crappie (Pomoxis annularis), pumpkin seed (Eupomotus gibbosus), and small mouth black bass (Micropterus dolomieu). Numerous experiments have also been run with various species of Cyprinid minnows. 


\section{PRESENTATION OF DATA}

\section{A. REACTION EXPERIMENTS}

\section{Reaction to chlorides}

The fishes used are less sensitive to the chlorides of the salts than they are to the nitrates and sulphates. They also react differently in the presence of different chlorides. Thus they are sensitive to both the anions and the kations, and to different degrees.

a. Ammonium chloride. The fishes were decidedly negative to this salt in $0.01 \mathrm{~N}$ concentration. The experiments were run in water that was a mixture of half aerated and half unaerated tap water (i.e., moderately acid with $\mathrm{CO}_{2}$ ). It has been found (Wells '15 a) that fishes give normal reactions in this water.

b. Potassium chloride. These experiments were also performed in water which was somewhat acid. The reaction of the fishes was rather peculiar in that they were positive to a higher concentration of this salt than was expected. Twenty-one experiments were performed and all showed this phenomenon. In a number of cases the fishes selected the highest concentration for a large part of the time. It was thought that the reaction might be due to the positiveness of the fishes for the chlorine ion, as will come out in other experiments; the known toxicity of the potassium ion, however, made this conclusion seem doubtful. Again, the fishes had been in the laboratory for over a month and were somewhat starved. It had already been determined that starvation increases the positiveness of some fishes to certain salts, and thus the reaction might be laid to this. However, the real explanation was later found to lie in a mutual antagonism which exists between certain salts and acids. Thus the reaction of the fishes in selecting the salt end was a reaction which brought them into the lesser stimulating part of the gradient. In the tap water end, the $\mathrm{CO}_{2}$ made the water quite acid. In the salt end this action of the acid was neutralized by the presence of the salt and vice versa. This phenomenon was noted in a number of the gradient experiments, while its cause was definitely proved in the resistance experiments. 
c. Sodium chloride. This was the first salt to be experimented with at the University of Illinois and a large number of experiments (46 in all) was performed with it, as the reactions of the fishes were not what was at first expected. Experiments were run in aerated (neutral) water, in moderately acid water (8-10 cc. per liter) and in strongly acid water (18 cc. $\mathrm{CO}_{2}$ per liter).

It had been noted that the f shes became sluggish when kept in the aerated water, and because they reacted positively to the $\mathrm{NaCl}$ in the gradients in this neutral water, the experiments were repeated in acid water to make the results certain. The fishes were positive to the $\mathrm{NaCl}$ half of the tank in all three kinds of water, but were markedly most positive in the most acid water. They are negative to this water alone, because of its marked acidity. The increase in positiveness to the $\mathrm{NaCl}$ in the acid water must be due to the fact that the salt antagonizes the stimulating action of the acid and thus the fishes selected the portion of the tank where they were the least stimulated, as they did in the case of the $\mathrm{KCl}$ gradient in acid water.

In an attempt to drive the fishes out of the salt end, the $\mathrm{NaCl}$ concentration was increased to $0.02 \mathrm{~N}$ but without diminishing the positive reaction. In the strongly acid water the fishes were found to give a positive reaction to as small a concentration of $\mathrm{NaCl}$ as $0.001 \mathrm{~N}$ though the reaction to this low concentration was not so definite as with the higher concentrations. The reaction to $\mathrm{NaCl}$ varied somewhat with the species; the crappies and bull-heads were positive in all three kinds of water while the blue-gills were positive in the neutral and strongly acid water but were indifferent to negative, in the moderately acid water.

Ten experiments with $0.01 \mathrm{~N} \mathrm{NaCl}$, in distilled water, were run to check those with the tap water. The results show the fishes to be markedly positive to the $\mathrm{NaCl}$ in distilled water gradients; this positiveness is not as great as in the acid water, but is great enough to show conclusively that the fishes used are positive to $\mathrm{NaCl}$ in concentrations very little lower than $0.01 \mathrm{~N}$.

d. Calcium chloride. Calcium chloride was the first salt used at Chicago in the gradient experiments. It was found that normal fishes (large rock bass are exceptions) are negative to 
a $0.01 \mathrm{~N}$ solution of this salt, and the graphs show this negativeness to be rather definite. The fishes turned back from the $\mathrm{CaCl}_{2}$ end at a point which the conductivity measurements showed to be about $0.0065 \mathrm{~N}$. Some of the apparently, normal fishes, however, gave positive reactions to $0.01 \mathrm{~N} \mathrm{CaCl}_{2}$ and in working out this point over 150 experiments were performed. A very interesting relation between starvation and the reaction of fishes to $\mathrm{CaCl}_{2}$, and probably some other salts, was found to exist. The experiments showing this relation will be discussed on a subsequent page under the heading, "Physiological states and the reactions of fishes" (p. 260).

e. Magnesium chloride. Normal fishes reacted negatively to a $0.01 \mathrm{~N}$ concentration of this salt, but as with calcium, there was a number of instances where the reaction seemed to be reversed. Normal fishes were also negative to a $0.02 \mathrm{~N}$ concentration, which however did not prevent a few of the fishes from showing a positive reaction, as they had done with the $0.01 \mathrm{~N}$ solution.

\section{Reaction to the nitrates}

The nitrate experiments, with the exception of part of those with calcium, were performed at Illinois. The experiments with the nitrate of calcium were performed largely at Chicago, enough being repeated at Illinois to correlate the reaction in the two waters.

a. Ammonium nitrate. Practically all the fishes used were negative to this nitrate, which is very stimulating to them, in tap water, as will be shown in the resistance experiments. They did not, however, avoid the salt end with as much precision as is displayed in the case of a number of the other salts, and in one experiment, a 25 -gram crappie, although giving a fairly strong negative graph, still was overcome by the salt, lost control of its movements, and 'scooted' about the tank, finally leaping over the edge onto the water table. Sixteen experiments were performed; of these fourteen show decidedly negative reactions, while two, one with a 3-gram blue-gill and one with a 6 -inch bull-head, show positive reactions. These two fishes were not 
overcome by the salt, though they remained in the salt end during a majority of the 15 minutes that they were in the tank.

b. Potassium nitrate. The fishes were consistently negative to this salt in $0.01 \mathrm{~N}$ concentration. Of 40 fishes tried in the gradient, 27 gave decidedly negative reactions, 5 stayed in the middle third of the tank, and 7 were more or less positive. In only 3 experiments was the time spent in the salt half of the tank, over 60 per cent of the total time. Of the 27 negative fishes, 20 spent over 80 per cent of the time in the tap water end.

c. Sodium nitrate. Experiments with all three kinds of water were run. In the neutral water the fishes were decidedly negative the graphs showing that 86 per cent of the time was spent in the tap water end of the tank. In the moderately acid water, 70 per cent of the reactions were negative and 30 per cent positive. In the strongly acid water, the fishes were decidedly positive to the $0.01 \mathrm{~N}$ concentration showing an 81 per cent positive reaction. The concentration of the salt was now decreased to $0.002 \mathrm{~N}$ and the same fishes tried. They were not so positive to this small concentration in the acid water as they had been to the $0.01 \mathrm{~N}$ solution but they were still more positive than in the moderately acid water. The graphs show 45 per cent of the time was spent in the salt third of the tank, 30 per cent in the middle third, and 25 per cent in the tap water third. These results show again the effect upon the behavior of the fishes, of the antagonistic reaction between the acid and the salt; they select the higher concentration of salt in the gradient in strongly acid water but are negative to this same concentration in water which is not so acid. Note also (table 1, p. 256) that the antagonism between the salts and the acid seems to be more marked in the case of the $K$ salts. Table 1 shows that in the case of both the chloride and nitrate of potassium the antagonism between the salt and the acid was sufficient to cause the fishes to react positively in moderately acid water. With sodium, the chloride shows a positive reaction in the moderately acid water but in this same water, the nitrate gives a negative reaction. It is not until the water has been made strongly acid that the fishes react positively to the nitrate of sodium. 
d. Calcium nitrate. At Chicago 20 (40-min.) experiments were run with this salt. The reactions of the fishes were so decidedly negative that further work seemed unnecessary. At the University of Illinois, it was decided to repeat the experiments with calcium nitrate as a check upon the reactions of the fishes in the two waters. To this end a series of experiments with $0.01 \mathrm{~N}$ $\mathrm{Ca}\left(\mathrm{NO}_{3}\right)_{2}$ in neutral water, was run. The results were very different from those obtained at Chicago. There the fishes had shown a 90 per cent negative reaction to this salt in $0.01 \mathrm{~N}$ concentration, while at Illinois in the neutral water, the reaction was 50 per cent negative and 50 per cent positive. In other words they seemed to be indifferent to the salt. It was thought that the explanation of the Illinois reaction might lie in the fact that, since calcium nitrate hydrolizes to give a faintly acid solution, the fishes, which (Wells '15 a) had already been shown to be negative to the neutral water, were reacting to this acidity. This proved to be the case, for when the experiments were repeated in moderately acid water, the fishes gave an 80 per cent negative reaction.

To make doubly sure of the results with the calcium nitrate, a final series of experiments was run in distilled water, which it will be remembered is slightly acid with $\mathrm{CO}_{2}$ (2-3 cc. per liter). Five 15-minute graphing experiments were run with results that show a 75 per cent negative reaction. An experiment with 4 bull-heads (3-5 in. long) was read 50 times at 30 second intervals. Computation showed that the fishes had spent 74 per cent of the time in the negative half of the tank. Thus the reactions at Chicago and at Illinois, when slightly acid water is used, are in close agreement in showing the negative reaction of fishes to $0.01 \mathrm{~N}$ concentration of calcium nitrate.

e. Magnesium nitrate. Twelve experiments were performed with this salt at Chicago; they showed a 100 per cent preference for the tap water half of the tank. The negativeness was more marked in some experiments than in others but in none did the fishes swim into the salt end. The experiments have not been repeated at Illinois. 


\section{Reaction to sulphates}

a. Ammonium sulphate. Fishes are negative to this salt as to the other ammonium salts. All the ammonium salts are strongly toxic to the fishes used. Especially is this toxic reaction noticeable in the tap water. The explanation for this will be taken up in the discussion of the resistance of fishes to ammonium salts.

b. Potassium sulphate. Fishes are decidedly negative to $0.01 \mathrm{~N}$ concentration of potassium sulphate. Twelve experiments were performed in moderately acid water and in none did the fishes give a positive reaction. In one the fish selected the middle third of the tank, but turned back regularly from the salt end. The results with this salt illustrate the increasing toxicity of the anion; it will be remembered that in moderately acid water the fishes gave a positive reaction to the nitrate of potassium. No experiments were performed at Chicago with this salt.

c. Sodium sulphate. No experiments were performed at Chicago with this salt. At Illinois two series were run, one in moderately acid water, and the other in strongly acid water. The reactions in the two kinds of water were very similar to those obtained with sodium nitrate in the same kinds of water. It was noted that in the strongly acid water the fishes often spent much of the time at the surface and were thus not swimming in the strongest gradient. For this reason the reactions might be expected to be somewhat less definite but the results show very little difference in cases where the fishes stayed at the bottom or swam at the surface. In 4 experiments the fishes spent practically all the time at the surface and 60 to 90 per cent in the salt half of the tank. In 8 experiments with this strongly acid water the fishes remained at the bottom throughout; seven of these experiments show a decided preference for the salt end while one was negative.

In the $\mathrm{NaNO}_{3}$ experiments, it will be remembered, the fishes were negative to the salt in moderately acid water and this was also found to be the case with the sulphate. Fifteen experi- 
ments with $0.01 \mathrm{~N} \mathrm{Na}_{2} \mathrm{SO}_{4}$ in moderately acid water were run. All of them show decidedly negative reactions. In a number of experiments the attempt was made to drive the fishes into the salt end, but with no success, except in one case, where a 20-gram crappie was driven into the salt end and remained there for 5 minutes before swimming back into the tap water end. The blue-gills could not be driven as they would dart back past the driving rod in every case. If these fishes were dropped into the salt end they showed much disturbance and very soon swam into the tap water end. In one experiment 8 small blue-gills (2-4 grams) were placed in the tank and readings of their position taken every 30 seconds until 25 readings had been made. The percentage of time spent in the thirds of the tank were, salt third 13 per cent, middle third 36 per cent and tap water third 51 per cent. Thus fishes are negative to $0.01 \mathrm{~N}$ sodium sulphate in moderately acid tap water but are positive to this concentration in strongly acid water. The explanation of this latter reaction must lie in the antagonism between the salt and the acid.

d. Calcium sulphate. These experiments (1.1 in all) were performed at the University of Illinois. The reaction in moderately acid water was negative in all but two cases. In one of these a fish which had at first selected the tap water end, was driven into the salt end, where it remained for the remainder of the experiment. An experiment in which 10 small blue-gills (2-4 grams) were placed in the tank and their positions read at 30second intervals, showed percentages as follows: Time spent in salt third 25 per cent, in middle third 32 per cent and in the tap water third 43 per cent.

e. Magnesium sulphate. Ten experiments with this salt were run at Chicago. All showed a negative reaction to the $0.01 \mathrm{~N}$ concentration and in most cases the reaction was very decided (usually above 80 per cent in tap end). The experiments were not repeated at Illinois. 


\section{Conclusions from reaction experiments}

We note from the data which have been given that fishes are markedly sensitive to salts in solution and that they react to them in a definite manner. They are negative to $0.01 \mathrm{~N}$ concentrations of most of the salts used, if in water which is moderately acid; this is the normal condition in most natural bodies of water. When the water becomes strongly acid, the reactions of the fishes are modified and may be reversed by the mutual antagonism which exists between salts and acids. So far as these experiments show, this antagonism exists only between the salts of $\mathrm{K}$ and $\mathrm{Na}$ and carbonic acid. From the general work upon the antagonism of salts, to be discussed later, one would not expect the antagonism to extend to the salts of $\mathrm{Ca}$ and $\mathrm{Mg}$. In the reaction experiments it was seen that the fishes are, in nearly all cases, positive to some concentration of the salt in question. This positiveness is most noticeable in the case of $\mathrm{NaCl}$. Table 1 is introduced to summarize the reactions of the fishes to $0.01 \mathrm{~N}$ salt concentrations in the different kinds of water used.

\section{B. ANTAGONIZING SALTS AND THE REACTIONS OF FISHES}

To determine whether or not fishes detect and react to combinations of salts in gradients, a number of experiments was performed, based upon the phenomena of the antagonistic reaction of salts, which are familiar to all biologists. These phenomena in their simplest form are expressed in the antagonism which exists between the salts of $\mathrm{Na}$ and $\mathrm{K}$, on the one hand, and $\mathrm{Ca}$ and $\mathrm{Mg}$, on the other. There has also been found a certain degree of antagonism between $\mathrm{Ca}$ and $\mathrm{Mg}$ in some cases (Meltzer and Auer '08). Most of the work on the antagonism of salts has been done either upon single organs as the heart, or other muscle tissue, or upon developing eggs and embryos. Certain combinations have also been shown to be best for preserving the life of fishes and other fresh water animals in distilled water (Ringer, etc.). So far as I am aware, no attempt has ever been made to determine the reactions of fishes to com- 
TABLE 1

Showing the reactions of fishes to $.01 N$ concentrations of various salts, in gradients of different kinds of water, i.e., waters of different degrees of acidity

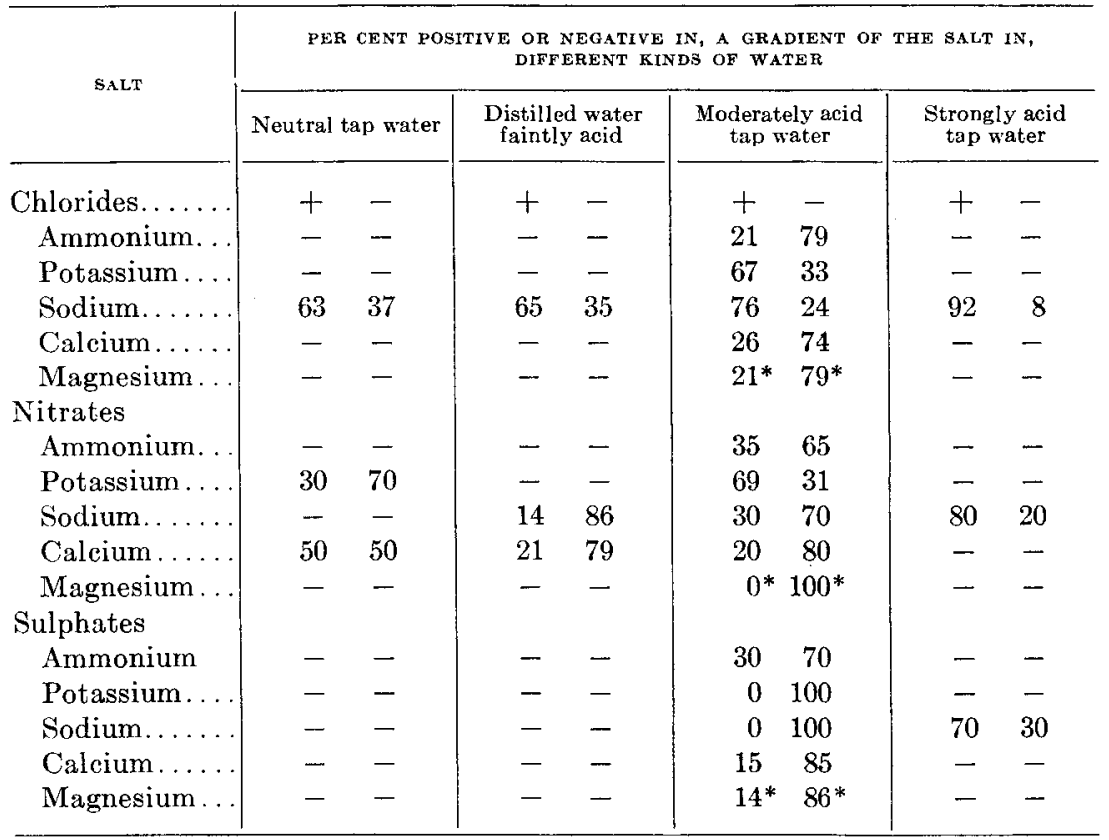

* Work done at Chicago.

\section{TABLE 2}

Comparing the reactions of fishes to single salts and to combinations of antagonistic salts. One salt is present in .01N concentration and the other as a trace $(.0002 N)$. Slightly acid tap contains $6-8 \mathrm{cc} . \mathrm{CO}_{2}$ per liter; strongly acid $18 \mathrm{cc} . \mathrm{CO}_{2}$ per liter; distilled water is fainty acid $\left(2-3 \mathrm{cc} . \mathrm{CO}_{2}\right.$ per liter $)$

\begin{tabular}{|c|c|c|c|}
\hline \multirow[t]{2}{*}{ SALT } & \multirow[t]{2}{*}{$\begin{array}{c}\text { KIND OF WATER ESED } \\
\text { IN GRADIENT }\end{array}$} & \multicolumn{2}{|c|}{$\begin{array}{l}\text { REACTION OF FISHES IN PER } \\
\text { CENT OF TIME SPENT IN HALVE } \\
\text { OF TANK. POSITIVE = IN SALT } \\
\text { HALF; NEGATIVE }=\text { IN TAP OH } \\
\text { DISTILLED WATER HALF }\end{array}$} \\
\hline & & $\begin{array}{l}\text { Per cent } \\
\text { positive }\end{array}$ & $\begin{array}{l}\text { Per cent } \\
\text { negative }\end{array}$ \\
\hline $\mathrm{NaNO}_{3}$ alone ...... & Slightly acid tap & 30 & 70 \\
\hline $\mathrm{NaNO}_{3}+$ trace $\mathrm{Ca}\left(\mathrm{NO}_{3}\right)_{2}$. & Slightly acid tap & 79 & 21 \\
\hline $\mathrm{NaNO}_{3}+$ trace $\mathrm{Ca}\left(\mathrm{NO}_{3}\right)_{2}$ & Strongly acid tap & 96 & 4 \\
\hline $\mathrm{Ca}\left(\mathrm{NO}_{3}\right)_{2}$ alone.......... & Slightly acid tap & 23 & 77 \\
\hline $\mathrm{Ca}\left(\mathrm{NO}_{3}\right)_{2}+$ trace $\mathrm{NaNO}_{3}$ & Slightly acid tap & 76 & 14 \\
\hline $\mathrm{Ca}\left(\mathrm{NO}_{3}\right)_{2}$ alone..... & Distilled water & 19 & 81 \\
\hline $\mathrm{Ca}\left(\mathrm{NO}_{3}\right)_{2}+$ trace $\mathrm{NaNO}_{3}$ & Distilled water & 87 & 13 \\
\hline $\mathrm{Ca}\left(\mathrm{NO}_{3}\right)_{2}+$ trace $\mathrm{Mg}\left(\mathrm{NO}_{3}\right)_{2}$ & Strongly acid tap & 53 & 47 \\
\hline
\end{tabular}


binations of salts in a gradient, and I present a number of experiments of this sort here. They show that fishes recognize and react to combinations of salts according to the prediction which might have been made from the results of previous work upon antagonism.

It will be remembered that fishes are slightly positive to $0.01 \mathrm{~N}$ $\mathrm{NaNO}_{3}$ in moderately acid water. It was found, however, that they are negative to this salt in water that is but faintly acid and for this reason the following experiments were run in water which contained less than $8 \mathrm{cc} . \mathrm{CO}_{2}$ per liter. The experiments were first run as regular salt experiments such as have been described before, and then the antagonizing salt was added to the salt flow. The concentration of the original salt was always $0.01 \mathrm{~N}$ and that of the antagonizing salt $0.0002 \mathrm{~N}$, i.e., a bare trace was added. The results of these experiments are shown in table 2. A considerable number of experiments was run with each combination in the tap water, and then some check experiments were run in distilled water. The results in the distilled water gradients are very similar to those in the tap water.

\section{Discussion of the experiments with antagonizing salt combinations}

Table 2 shows clearly that the antagonistic action of the salts is detected and reacted to by the fishes. This is shown, for instance, in the sodium nitrate experiments; here the fishes were 70 per cent negative to this salt in slightly acid water but when a trace of calcium nitrate was added the negative response fell off to 21 per cent and the positive rose from 30 to 79 per cent. Then in strongly acid water the positive response increased to 96 per cent. The reactions of fishes in any gradient are due to their tendency to move about until they reach an environment that neither over- nor under-stimulates them. Thus they will not remain quietly in water that is strongly acid nor will they do so in water that is neutral. A slight degree of acidity (1-6 cc. $\mathrm{CO}_{2}$ per liter, Wells '15 a) furnishes their optimum stimulation as far as $\mathrm{H}$ ion is concerned. The reversal in reaction of the fishes in gradients to which a trace of an antagonistic salt 
has been added, must then be due to the fact that this trace of salt lessens the stimulation in the salt end of the gradient. There are three principal factors affecting the degree of stimulation of the gradients referred to in table 2 , namely, the original salt (e.g., $\mathrm{NaNO}_{3}$ ) the antagonising salt (e.g., $\mathrm{Ca}\left(\mathrm{NO}_{3}\right)_{2}$, and the acid. Before the antagonising salt was added the fishes were negative to the original salt, even though this meant spending most of the time in a degree of acidity which was slightly above their optimum. With the addition of the antagonising salt, however, they reversed their reaction and became positive to the salt end. The antagonising salt must have diminished the original stimulation in the salt end or have increased the stimulation in the acid end, or both. The work upon the effect of acids and salts upon permeability suggests that both factors were concerned. Lillie ('10) has shown that calcium salts decrease the permeability of egg membranes while the salts of sodium increase the permeability. Osterhout ('12, a and b) has shown that sodium salts increase the permeability of plant cells while the addition of a trace of calcium salt maintains normal permeability even in the presence of an excess of the sodium salt. Osterhout has also shown that there exists a mutual antagonism between certain acids and salts as for instance between $\mathrm{HCl}$ and $\mathrm{NaCl}$, but the salts of calcium and magnesium work with rather than against the acid.

In the above experiment, therefore, the addition of the calcium salt to the end of the gradient which contained a sodium salt in concentration strong enough to cause the fishes to give a negative reaction, resulted in the fishes becoming positive. This reversal in the reaction of the fishes must have been due to the decrease in the stimulating power of the salt end. It has already been shown that increasing the acidity of water will cause fishes to become positive to concentrations of sodium salts to which they are normally negative (table 2) and it was found that the higher the acidity the higher was the concentration of sodium salt selected by the fishes.

Table 2 also shows that the antagonistic action between calcium and sodium salts is detected and reacted to, when the con- 


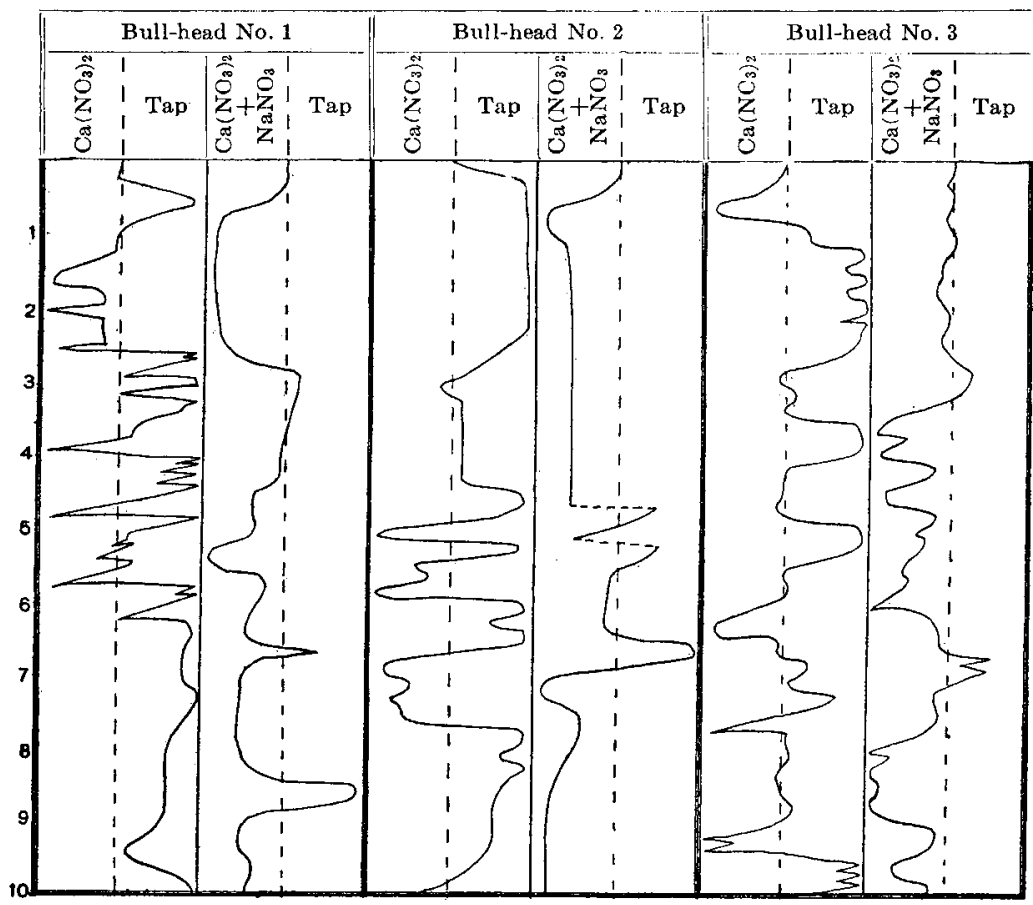

Fig. 2 Showing the reaction of bull-heads (Ameiurus melas) to $\mathrm{Ca}\left(\mathrm{No}_{3}\right)_{2}$, alone, and in combination with a trace of $\mathrm{NaNO}_{3}$. The concentration of the calcum salt was $0.01 \mathrm{~N}$ throughout and that of the sodium salt $0.0002 \mathrm{~N}$; experiments performed in distilled water; numbers at left indicate time in minutes.

centrations of the two salts are reversed, i.e., when the calcium nitrate is present in $0.01 \mathrm{~N}$ concentration and the sodium as a trace $(0.0002 \mathrm{~N})$. The data for table 2 were obtained from graph experiments and also from readings. The same fishes were used in the gradient with the different conditions, i.e., they were first graphed in the gradient with the sodium salt (e.g.) alone and then again after the calcium salt had been added to the flow. To illustrate more accurately this method of experiment figure 2 is inserted. The graphs shown in this figure are 3 of those made by 4 bull-heads. The experiments were run as follows: The gradient with only $\mathrm{Ca}\left(\mathrm{NO}_{3}\right)_{2}$ flowing in at the salt end, was obtained by allowing the flow to continue for 30 
minutes. The fishes were then taken from the large aquarium and placed in pans of water, numbered 1, etc. The fish from pan No. 1 was placed in the gradient and its movements graphed for 15 minutes. It was removed and No. 2 was placed in the gradient and graphed. This was repeated for Nos. 3 and 4. A trace of $\mathrm{NaNO}_{3}$ was now added to the inflow at the salt end; after 20 minutes fish No. 1 was again placed in the gradient and its movements graphed for 15 minutes. This was repeated for the three remaining fishes in the same order as before. The graphs show the marked difference in the reactions of the fishes before and after the trace of sodium nitrate was added.

\section{PHYSIOLOGICAL STATES AND THE REACTIONS OF FISHES}

In the discussion so far attention has been called to the fact that in most of the series of experiments, there was a small percentage of the fishes (usually $3-5$ per cent) which gave reactions more or less the reverse of those given by the majority. Such exceptions to the general behavior are common in experimental work of all sorts and probably indicate physiological differences upon the part of the organisms. That such physiological differences, i.e., physiological states, exist and that they influence very markedly the reactions of the animals has been proven beyond doubt (Child '13, and Allee '12). Allee and Tashiro ('14) have shown that the reactions of isopods are very closely correlated with the metabolic activity and Allee ('12) has shown that by changing the rate of metabolism he can alter and even reverse the reaction of isopods to current. A correlation between the rate of metabolism and the reactions of amphipods has been shown by Phipps ('15).

At Chicago during the winter of 1913-1914, a study not yet published was being made of the effect of starvation upon the resistance of fishes to $\mathrm{KCN}$ and low oxygen; it was thought that the starving fishes furnished good material for ascertaining during the same period something of the effects of starvation upon the reactions of fishes in gradients. Accordingly a series of 89 experiments was run with the starving fishes in gradients; 50 
of the experiments were in gradients of $\mathrm{CaCl}_{2}$ since it seemed best to confine the experiments to a few salts at the most. It was decided that the starving fishes should not be handled to any great extent during the obtaining of the data for which the material was originally intended. A few experiments were run in gradients of $\mathrm{Ca}\left(\mathrm{NO}_{3}\right)_{2}$ and $\mathrm{MgCl}_{2}$ the results of which were. much like those for $\mathrm{CaCl}_{2}$. Nine expriments with starving fishes in low oxygen gradients are included as they are significant.

The experiments with starvation and resistance of fishes showed in brief the following points: The fishes as they began to starve became more resistant to KCN and low oxygen. This rise in resistance which is a decrease in susceptibility, continued for some weeks (varied with species). There was then a rather sudden decrease in resistance (increase in suseptibility) which was found to be a close fore-runner of death. In terms of metabolism, as starvation in certain fishes proceeds the rate of metabolic acitvity is at first decreased. After remaining below normal for some weeks (or even months) the forces which are inhibiting the rate of reaction, give way and the rate runs up rapidly to, and beyond, the normal rate. Whether the changes in the physiological condition of the fishes are wholly quantitative is not certain. It is very probable that a change in the rate of metabolism does not express all that takes place but there may be alterations in the kind of metabolism also; in other words starvation in fishes may produce qualitative as well as quantitative changes in metabolism.

Starvation experiments were run with several species of fishes including the rock bass (Ambloplites rupestris), small mouth black bass (Micropterus dolomieu), pumpkin seed (Eupomotus gibbosus), mud minnow (Umbra limi), and the black bull-head (Ameiurus melas). The fishes seemed to be divided into two groups as far as their starvation reactions are concerned. The bull-heads made up one group and the other fishes a second. Most of the work was done with the bull-heads and the rock bass as representatives of the two groups. In the case of the rock bass some quantitative data can be presented. 


\section{Reactions of starved fishes to $\mathrm{CaCl}_{2}$}

Normal bull-heads are negative to $0.01 \mathrm{~N}$ calcium chloride in a gradient. It was noticed, however, that when food was given these fishes they often became positive to the salt half of the tank. To check this reaction 23 experiments with normal, well fed and starved bull-heads were run. Table 3 shows the results obtained. It shows that normal fishes (bull-heads) are negative to $0.01 \mathrm{~N}$ calcium chloride well-fed ones positive, and starved negative again. The well-fed bull-heads were in fact given all the food they would eat and thus were really over fed, as they ate until their abdomens were much puffed out. The data in

TABLE 3

Showing the reactions of normal, over-fed, and starved bull-heads (Ameiurus melas) to .01N calcium chloride, in a gradient. Data shows per cent of time spent in the halves of the tank

\begin{tabular}{|c|c|c|c|c|c|c|}
\hline \multirow{2}{*}{ FISH NUMBER } & \multicolumn{2}{|c|}{ NORMAL REACTION } & \multicolumn{2}{|c|}{ OVER-FED REACTION } & \multicolumn{2}{|c|}{ STARVED REACTION } \\
\hline & $\mathrm{CaCl}_{2}$ & Tap & $\mathrm{CaCl}_{2}$ & Tap & $\mathrm{CaCl}_{2}$ & Tap \\
\hline 1 & 29 & 71 & 66.5 & 33.5 & 32 & 68 \\
\hline 2 & 44 & 56 & 78 & 22 & 63 & 37 \\
\hline 3 & 34 & 66 & 57 & 43 & 29 & 71 \\
\hline 4 & 37 & 63 & 73 & 27 & 40 & 60 \\
\hline 5 & 31 & 69 & 78 & 22 & 52 & 48 \\
\hline
\end{tabular}

table 3 is taken from the graphs made with 5 fishes. The normal reaction of each fish was determined immediately upon bringing it into the laboratory from the streams. On the next day the fishes were fed all the beef they would eat and graphed again on the third day. They were then starved and graphed from day to day. The figures in column 4, table 2, are those obtained after from 5 to 10 days starving. Each day calcium chloride was run into the end of the tank opposite that of the day before.

The method of experimenting with the rock bass in the resistance experiments was to bring them in from the creeks in which they live and to weigh them individually, and at once. The process of starvation was then kept track of by successive weighings. Twenty-six experiments with these starving fishes were 
run to determine the effect of the starvation upon the reaction to $\mathrm{CaCl}_{2}$. It will be recalled that normal rock bass are negative to this salt in $0.01 \mathrm{~N}$ concentration (except in the case of large fishes). The starving rock bass were therefore experimented upon in gradients of $\mathrm{CaCl}_{2}$ at different stages of starvation, with results such as those shown in table 4 . This table shows that starvation increases the percent of positiveness of these fishes. This is true for that period of starvation, during which the rate of metabolism is slowed up. The few experiments that were performed upon fishes in which the factors inhibiting starvation had broken down and the rate of metabolism had gone above normal, indicate that the fishes are again negative to $\mathrm{Ca}$ salts at this time.

\section{TABLE 4}

Showing the reactions of normal and starved rock bass (Ambloplites rupestris) to $.01 \mathrm{~N}$ concentrations of $\mathrm{CaCl}_{2}$ in a gradient. Reactions are shown in per cent of time spent in the two halves of the gradient tank

\begin{tabular}{|c|c|c|c|c|c|c|}
\hline \multirow{2}{*}{ FISH NUMBER } & \multirow{2}{*}{$\begin{array}{l}\text { CATE OF } \\
\text { COLLECTION }\end{array}$} & \multirow{2}{*}{$\begin{array}{c}\text { DATE OF } \\
\text { EXPERI- } \\
\text { MENT }\end{array}$} & \multirow{2}{*}{$\begin{array}{c}\text { ORIGINAL } \\
\text { WEIGHTIN } \\
\text { GRAMS }\end{array}$} & \multirow{2}{*}{$\begin{array}{c}\text { WEIGHT } \\
\text { AT TIME OF } \\
\text { EXPERIMENT }\end{array}$} & \multicolumn{2}{|c|}{$\begin{array}{l}\text { REACTION IN PER CENT } \\
\text { OF TIME IN }\end{array}$} \\
\hline & & & & & $\mathrm{CaCl}_{2}$ & Tap water \\
\hline & 1913 & 1913 & & & & \\
\hline 1 & Nov. 20 & Nov. 23 & 9.9 & 8.9 & 30 & 70 \\
\hline 2 & 20 & 23 & 23.1 & 22.5 & 43 & 57 \\
\hline 3 & 20 & 23 & 56.2 & 54.5 & 38 & 62 \\
\hline 4 & 20 & 23 & 70.6 & 68.4 & 22 & 78 \\
\hline 5 & 20 & 23 & 126.0 & 124.0 & 90 & 10 \\
\hline 6 & Oct. 16 & 23 & 21.1 . & 18.6 & 100 & 0 \\
\hline 7 & 16 & 23 & 66.0 & 61.7 & 30 & 70 \\
\hline 8 & 16 & $\begin{array}{r}23 \\
1914\end{array}$ & 90.9 & 77.0 & 10 & 90 \\
\hline 9 & Dec. 6 & April 9 & 97.0 & 64.2 & 38 & 62 \\
\hline 9 & 6 & 10 & 97.0 & 64.0 & 73 & 27 \\
\hline 9 & 6 & 10 & ends of grac & ent reversed & 82 & 18 \\
\hline 9 & 6 & 15 & 97.0 & 67.3 & 34 & 66 \\
\hline 9 & 6 & 15 & ends of grad & ent reversed & 30 & 70 \\
\hline 9 & 6 & 16 & 97.0 & 65.0 & 67 & 33 \\
\hline 9 & 6 & 17 & 97.0 & 62.3 & 76 & 24 \\
\hline 10 & 6 & 5 & 83 & 64.2 & 46 & 54 \\
\hline 10 & 6 & 10 & 83 & 61.7 & 61 & 39 \\
\hline 10 & 6 & 10 & ends of grac & ent reversed & 58 & 42 \\
\hline 10 & 6 & 16 & 83 & 61.0 & 60 & 40 \\
\hline
\end{tabular}


Note (table 4) that the normal fishes were negative to $0.01 \mathrm{~N}$ $\mathrm{CaCl}_{2}$, that with the small fishes this reaction had become positive by the end of a little over a month (fish No. 6) while the larger fishes were still negative. Fishes Nos. 9 and 10 show the reaction of fishes starved for almost four months. These fishes were kept in running water and probably obtained a little food but the successive weighings showed that the process of starvation was a continuous one. Note the reversal in reaction of fish No. 9. The first experiment with this fish shows it to be slightly negative. On the next day it had become positive, as was shown by two experiments, with the salt flow at one end of the gradient tank in one, and reversed in the other. The weighings show that the fish had increased in weight since the day before and this increase must have been due to the securing of food in some way; the food had temporarily restored the normal reaction. However, by the next day the weight had again fallen off and the fish was once more positive to the salt, as is characteristic for starving fishes.

\section{Reaction of starved fishes to low oxygen}

The results of the experiments with starved fishes (rock bass) in low oxygen gradients are seen in table 5, which shows that

TABLE 5

Showing the reactions of normal and starved rock bass to low oxygen in a gradient.

Reactions are expressed in per cent of time in the halves of the tank (work done at Chicago)

\begin{tabular}{|c|c|c|c|c|c|c|}
\hline \multirow{2}{*}{ FXSH NUMBER } & \multirow{2}{*}{$\mid \begin{array}{c}\text { DATEE OF } \\
\text { COLLECTION }\end{array}$} & \multirow{2}{*}{$\begin{array}{c}\text { DATE OF } \\
\text { EXPERI- } \\
\text { MENT }\end{array}$} & \multirow{2}{*}{$\begin{array}{l}\text { ORTGINAL } \\
\text { WEIGHT }\end{array}$} & \multirow{2}{*}{$\begin{array}{c}\text { WT. AT } \\
\text { AT TIME } \\
\text { OF EXPT. }\end{array}$} & \multicolumn{2}{|c|}{$\begin{array}{l}\text { REACTIONS IN PER CENT } \\
\text { OF TIME IN }\end{array}$} \\
\hline & & & & & Low $\mathrm{O}_{2}$ & Tap water \\
\hline Normal fishes & 1913 & 1913 & & & & \\
\hline 1 & Nov. 20 & Nov. 22 & 1.7 & 1.5 & 5 & 95 \\
\hline 2 & 20 & 22 & 9.9 & 9.5 & 25 & 75 \\
\hline 3 & 20 & 22 & 23.1 & 22.5 & 32 & 68 \\
\hline 4 & 20 & 22 & 70.6 & 69.0 & 20 & 80 \\
\hline 5 & 20 & 22 & 126.0 & 124.0 & 91 & 9 \\
\hline Starved fishes & & & & & & \\
\hline 6 & Oct. 16 & 22 & 21.1 & 18.6 & 44 & 56 \\
\hline 7 & 16 & 22 & 66.0 & 61.7 & 50 & 50 \\
\hline 8 & 16 & 22 & 90.9 & 77.0 & 34 & 66 \\
\hline
\end{tabular}


normal rock bass are negative to low oxygen ( 1 cc. per liter at the low end) as has been shown also by Shelford and Allee ('13, p. 236). Large rock bass seem to be an exception to this general rule as they are not always negative to low oxygen, and in some cases seem to definitely prefer the low oxygen end of the gradient, spending a majority of the time there. The cause of this reaction has not been determined but it may have to do with the concentration of hydrogen ion which would probably be a little higher in the low oxygen end than in the high oxygen water, the difference being due to the difference in the effect of the two kinds of water upon the elimination of carbon dioxide by the organism.

Fishes Nos. 6 to 8 (table 5) are the individuals occurring under the same numbers in table 4 . There it was noted that their reaction to the $\mathrm{CaCl}_{2}$ had become more positive than the normal reaction and in table 5 it will be noted that these fishes are less sensitive to the low oxygen also. Fish No. 5 is also the same in tables 4 and 5 and it will be noted that this fish was positive to both low oxygen and $0.01 \mathrm{~N} \mathrm{CaCl}_{2}$. Experiments in low oxygen gradients were not performed with these fishes later in their period of starvation but the data given indicate that as they become somewhat starved they at the same time become less negative to low oxygen. This indicates that their metabolic rate is slower than normal.

\section{ACCLIMATIZATION AND THE REACTION OF FISHES}

During the course of the experiments, considerable evidence was accumulated concerning the effect of acclimatization upon the reactions of the fishes. A few experiments with fishes in $\mathrm{CO}_{2}$ gradients indicated that these fishes after living for two to three weeks in water whose $\mathrm{CO}_{2}$ concentration was 8 to 10 cc. per liter, were more sensitive to the $\mathrm{CO}_{2}$ than normal fishes. To determine whether or not the presence of an excess of salt would result in similar reactions to the salt in a gradient, a series of acclimatization experiments with $\mathrm{CaCl}_{2}$ was run.

A medium-sized (45-gram) rock bass was graphed in a $\mathrm{CaCl}_{2}$ gradient; its normal reaction was decidedly negative to $0.01 \mathrm{~N}$ 
$\mathrm{CaCl}_{2}$. It was now placed in a 20 -gallon-jar full of a $0.01 \mathrm{~N}$ solution of this salt. Each succeeding day it was taken from the jar and its reaction in the gradient graphed, when it was returned to the jar. This was continued for 6 days; the concentration of the solution in the jar was then riased to $0.05 \mathrm{~N}$. The fish was left in this solution 4 days longer, being graphed each day. It was then returned to the tap water and graphed again after 2 days. In making the graphs each day, the salt solution was run into the end of the gradient tank, opposite that of the day before. A series of the graphs made by this fish are shown in figure 3. They show the different stages in the process of acclimatization. In short they indicate that the

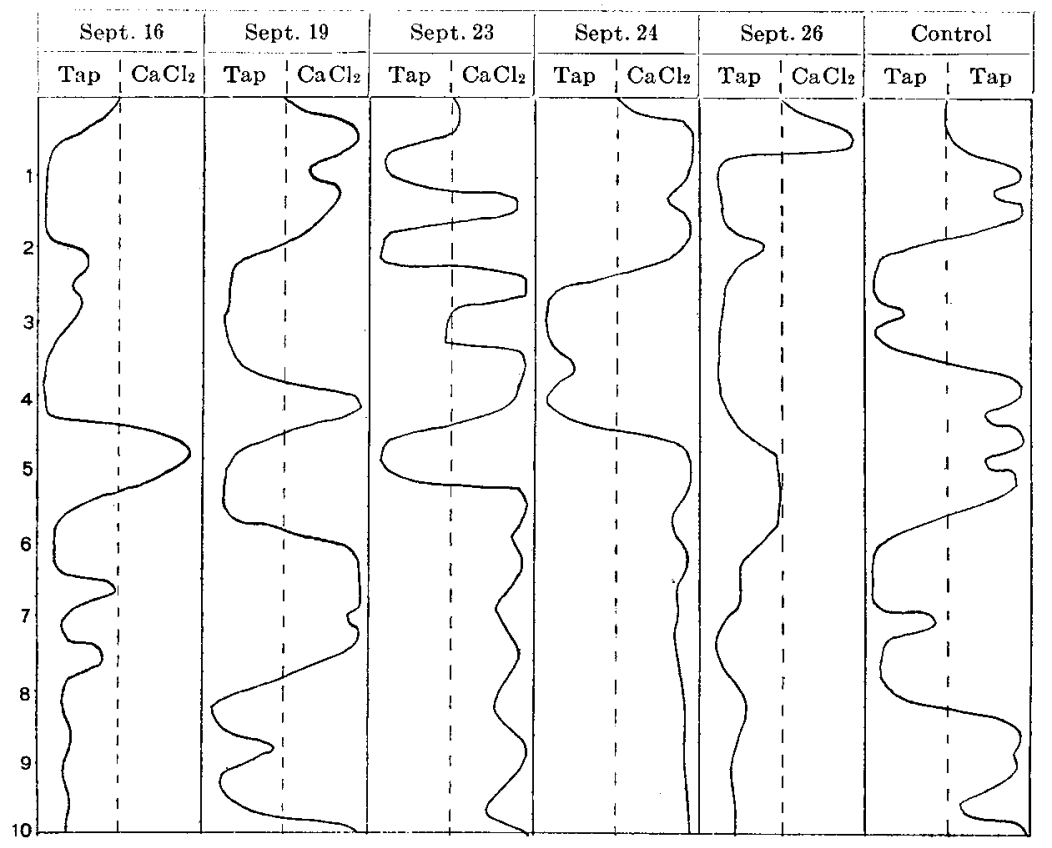

Fig. 3 Showing the reversal in reaction to $0.01 \mathrm{~N} \mathrm{CaCl}_{2}$, upon the part of a 45-gram rock bass (Ambloplites rupestris), after being kept in the salt solution for a week, and the return to normal reaction upon being placed in tap water again. In the experiments the salt was made to flow into alternate ends, but in the chart the graphs have been copied so that the reaction will be more easily seen, by keeping the same relation between the tap and $\mathrm{CaCl}_{2}$ ends. 
fish did become acclimated to the $\mathrm{CaCl}_{2}$ solution by the end of a week and selected the higher concentration in the gradient. Then after 2 days in the tap water it was negative to the salt again.

A like set of experiments was performed with a small bullhead (6 in. long) with similar results; the acclimatization, however, came sooner. Neither of the fishes was fed while in the $\mathrm{CaCl}_{2}$ and this would have an effect upon their reaction. The fact that the rock bass became negative again after being returned to the tap water indicates that the starvation did not account for its positive reaction while being kept in the $\mathrm{CaCl}_{2}$ solution. Starvation would tend to increase the negativeness of bullheads to the salt so the positive reaction upon being kept in the $\mathrm{CaCl}_{2}$ can be due to nothing but acclimatization. The difference in the effect of starvation upon the reactions of the two species of fishes to salts is probably due to a difference in the metabolism of the fishes and will be discussed in another paper.

\section{E. RESISTANCE OF FISHES TO SALTS}

The toxic effect of certain salts upon organisms has been the subject for considerable investigation upon the part of other workers (Ringer, Loeb, R. Lillie, and others) and therefore considerable is known concerning the relative toxicity of the various salt ions. In the present paper are presented data which indicate that much of the work upon the toxicity of salts must be reconsidered and correlated with the chemical reaction of the water. The data show that the poisonous properties of a given salt may vary within wide limits depending upon the amounts of hydrogen or hydroxyl ions present in the solution.

\section{Resistance to ammonium salts}

According to Mathews ('07) the pharmacological action of most salts is due to the ions of the salt. The kind of action depends upon the character of the charge of the ion, i.e., whether positive or negative; the degree of action is proportional to the available energy in the ion. Ammonia salts are peculiar, how- 
ever, in that their toxicity is not due to the action of either of the original ions, but to the products which are derived from the breaking down of the original ammonia compound. Ammonia salts in solution dissociate principally into $\mathrm{NH}_{4}$ ions and the acid ion with which the ammonia is combined. There is a hydrolytic dissociation also, so that there is always present in the solution a small amount of the free acid and the ammonium hydrate. In considering the reactions of fishes to ammonium hydrate (Wells, '15a, p. 236) it was pointed out that the ammonium hydrate in solution is in equilibrium with and is but a small per cent of the dissolved ammonia gas. In the case of an ammonia salt the hydrolytic dissociation of the salt produces the hydrate, which in turn dissociates to give water and ammonia gas. The amount to which the salts dissociates into ammonium hydrate and ammonia gas varies with the salt, being least in the sulphate and larger in the carbonate (Mathews, l.c.). Mathews further states that it is probable that the action of the ammonium salts is due, therefore, to the hydrate which is formed, and in turn the action of the hydrate is dependent upon the action of the dissociated $\mathrm{NH}_{3}$. This gas is probably in a nascent condition just at its moment of origin, when the valencies of the nitrogen are still open.

The toxic action of the ammonium salts used in the reaction experiments was found to be very marked when they were dissolved in the tap water, but was much less when the salts were dissolved in distilled water. Solutions $(0.01 \mathrm{~N})$ of the chloride, nitrate and sulphate were made up in tap and distilled water and small blue-gills (3-gram) were placed in jars of the different solutions. The temperature was kept constant by setting the jars in running tap water. One liter of solution was contained in each; the results are shown in table 6.

The marked increase in the longevity of the fishes in the distilled water seemed worthy of further investigation. Death in the distilled water was in part due to increasing acidity of the solution, as titrations showed a concentration of hydrogen ion at the end of the experiments that must soon have killed the fishes even though no other factor were present. This increase 
TABLE 6

Showing the resistance of small blue-gills (3-gram) to $.01 N$ concentrations of the chlolide, nitrate and sulphate of ammonium dissolved in tap and distilled water

\begin{tabular}{|c|c|c|c|}
\hline \multirow{2}{*}{ KIND OF WATER } & \multicolumn{3}{|c|}{ DXING TIME IN THE SOLUTIONS } \\
\hline & Chloride & Nitrate & Sulphate \\
\hline Tap water from aquarium.. & 4.8 hours & 3.9 hours & 3.5 hours \\
\hline Distilled water........ & 18 days & 16 days & 17 days \\
\hline
\end{tabular}

in the acidity of the solutions was marked in the case of all three salts and the titrations showed that the acidity upon the day of death of the fishes, had increased to nearly $0.001 \mathrm{~N}$ while $0.0001 \mathrm{~N}$ is enough to kill these fishes in distilled water when no salt is present. The increase in acidity was not due entirely to the $\mathrm{CO}_{2}$ given off by the fishes, as boiling did not remove it. It must, therefore, have come from the acid which had formed from the hydrolysis of the salt. The ammonia formed in the same process had passed off into the atmosphere. It seems clear then that the three salts in question do not furnish a large enough quantity of $\mathrm{NH}_{3}$ to kill the fishes, if the salts are dissolved in distilled water.

It has been pointed out in a previous paper (Wells ' 15 a) that the tap water at the University of Illinois contains an unusually large amount of the bicarbonates of $\mathrm{Ca}$ and $\mathrm{Mg}$ and that as the water is aerated these bicarbonates dissociate to give the normal carbonate. It was thought that the toxicity of the ammonium salts in the tap water may have been due to the formation of ammonium carbonate and the further dissociation of this salt to give $\mathrm{NH}_{3}$ in toxic quantities. To test this possibility three experiments with $0.01 \mathrm{~N}$ concentrations of $\left(\mathrm{NH}_{4}\right)_{2} \mathrm{CO}_{3}$ in distilled water, were tried. The dry salt gave a strong odor of ammonia but the solution was too dilute to give any odor at all. After thoroughly shaking the solution and allowing it to stand for 10 minutes, a 10-gram sun-fish was placed in a liter of it. A control was run in distilled water. The result of this experiment, together with those obtained from a number of other experiments are given in table 7 . The table shows that am- 
monium carbonate is very toxic in distilled water, that standing does not lessen its toxicity greatly nor does it that of the sulphate in tap water, and finally that the ammonium sulphate is no longer toxic in tap water when the carbonates have been converted into sulphates by the addition of enough sulphuric acid to make the water neutral to methyl orange.

TABLE 7

Showing the resistance of fishes to $.01 \mathrm{~N}$ concentrations of $\left(\mathrm{NH}_{4}\right)_{2} \mathrm{CO}_{3}$ in distilled water; the effect of standing upon the toxicity of ammonium salt solutions; and the non toxicity of a solution of $\left(\mathrm{NH}_{4}\right)_{2} \mathrm{SO}_{4}$ in tap water when the carbonates have been converted into sulphates.

\begin{tabular}{|c|c|c|}
\hline \multirow{2}{*}{ SOLUTION } & \multicolumn{2}{|c|}{ DYING TIME OF THE FISH IN THE } \\
\hline & Experiment & Control \\
\hline $\begin{array}{l}0.01 \mathrm{~N}\left(\mathrm{NH}_{4}\right)_{2} \mathrm{CO}_{3} \text { in distilled } \mathrm{H}_{2} \mathrm{O} \ldots \ldots \ldots \\
\text { Same after standing } 24 \text { hrs } \ldots \ldots \ldots \ldots \ldots \\
0.01 \mathrm{~N}\left(\mathrm{NH}_{4}\right)_{2} \mathrm{SO}_{4} \text { in tap water } \ldots \ldots \ldots \ldots \\
\text { Similar solution after } 24 \text { hrs. } \ldots \ldots \ldots \ldots \\
0.01 \mathrm{~N}\left(\mathrm{NH}_{4}\right)_{2} \mathrm{SO}_{4} \text { in tap water after the } \\
\text { carbonates have been changed to sul- } \\
\text { phates. } \ldots \ldots \ldots \ldots \ldots \ldots \ldots \ldots \ldots\end{array}$ & $\begin{array}{l}1.7 \text { hours } \\
2.2 \text { hours } \\
1.3 \text { hours } \\
2.2 \text { hours }\end{array}$ & $\begin{array}{c}\text { normal } \\
\text { normal } \\
\text { normal } \\
\text { normal }\end{array}$ \\
\hline
\end{tabular}

The experiments upon the resistance of fishes to ammonium salts show clearly that ammonia in any form is toxic to fishes in water containing carbonates. Since practically all natural waters contain a greater or lesser amount of the carbonates in solution as such, or as bicarbonates, the introduction of even very small amounts of ammonia into these waters will be very detrimental to the fishes. Table 7 shows, on the other hand, that the carbonates are not necessary to the immediate existence of the fishes, i.e., the water need not be alkaline to methyl orange as Marsh ('07) claimed. It may of course be that the carbonates are necessary to a successful completion of the life history of some fishes, or to the continued existence of certain species. This point has not been worked out so far as I am aware. 


\section{Resistance to potassium salts}

Solutions $(0.01 \mathrm{~N})$ of the chloride, nitrate, and sulphate, were made up in tap water and a small blue gill (3-5 gram) introduced into a liter of each; the results are shown in table 8 .

The action of the potassium salts in tap water was checked by placing a fish in a $0.01 \mathrm{~N}$ solution of the most toxic one, i.e., the sulphate, in distilled water. The reactions of this fish were very peculiar. After 3 days in the solution it was noticed that the fish was losing its equilibrium and it was expected that it would die in a few hours. On the next day, however, it was still

TABLE 8

Showing the resistance of small blue gills to $.01 N$ concentrations of potassium salts in solution in tap water

\begin{tabular}{c|c|c}
\hline Chloride & DYing TIME IN \\
\hline Normal on 15 th day.......... & 15 days & Sulphate \\
\hline
\end{tabular}

alive and for 10 days more it lived spending much of the time lying on its side but righting itself when touched with a glass rod. Its movements were sluggish and stiff, much as though it were dying from fungus disease. In all, the fish lived for 14 days in $0.01 \mathrm{~N}$ potassium sulphate solution, which is over three times as long as a fish of the same size lived in the same strength solution in tap water. The long-drawn-out death of the fish is not a phenomenon that is peculiar to potassium salts, however, for it was noted that another small blue gill which was in an ammonium nitrate experiment in distilled water at the same time, gave a similar reaction. This latter fish swam about for three days on its side with the body bent into the bow-shape that often distorts fish after death, especially when they dry out. This suggests that the distortion may have been due to osmotic changes in the tissues. 


\section{Resistance to sodium salts}

Experiments with the following sodium salts were performed in tap water: bicarbonate, carbonate, chloride, nitrate, and sulphate. The solutions were $0.01 \mathrm{~N}$ and the fishes small blue gills $(3-5$ grams $)$. The results were as follows:

$\quad$ Salt used
Sodium bicarbonate
Sodium carbonate
Sodium chloride
Sodium nitrate
Sodium sulphate
Resistance of fishes
Normal at end of 15 days; discont.
Dead after 3 days
Normal after 19 days; discont.
Dead after 31 days; only $50 \mathrm{cc}$. water left
Normal after 20 days; discont.

From the above results we see that the sodium salts are not toxic to blue gills when $0.01 \mathrm{~N}$ concentrations are used in tap water. The carbonate is an exception as the fish dies in this solution in 3 days. It has already been shown (Wells '15 a) that these fishes cannot live in water that is even faintly alkaline and thus the action of the carbonate is due to its alkalinity.

It will be remembered that the reactions of the fishes in salt gradients were complicated by the antagonism between the salts and the acid in the water. Loeb was the first to demonstrate that there exists an antagonism between salts and acids, as in 1899 he showed that acid antagonises the effect of $\mathrm{NaCl}$ on the swelling of muscle. He suggested that the antagonism depends upon the action of the substances upon the proteins of the tissues. Again, Loeb and Wasteneys ('11 and '12) demonstrated the antagonism between salts and acids, in their effect upon the marine fish Fundulus and explained the effect as due to a direct action on permeability. Osterhout ('14) made investigations which show that similar though less striking antagonism between acids and $\mathrm{NaCl}$ occurs in plants; he further states that the antagonism is not as great as that between $\mathrm{NaCl}$ and $\mathrm{CaCl}_{2}$.

To determine the relation of the antagonism between salts and acids to the resistance of fresh water fishes, a series of experiments was run with $\mathrm{NaCl}$ and $\mathrm{HCl}$. Table 9 summarizes the results of these experiments. From this table it will be noted that fresh water fishes of the same species and size live much longer in toxic 
TABLE 9

Showing the antagonism of $\mathrm{NaCl}$ and $\mathrm{HCl}$ in their toxic action upon fishes; experiments performed in distilled water (U. of $I$.

\begin{tabular}{|c|c|c|}
\hline SIZE AND SPECIES OF FISH & KIND OF SOLUTHON & $\begin{array}{l}\text { DYING TIME } \\
\text { TN HOURS }\end{array}$ \\
\hline 25 -gram rock bass. & $0.25 \mathrm{~N} \mathrm{NaCl}$ & 18 \\
\hline 23 -gram rock bass..... & $0.25 \mathrm{~N} \mathrm{NaCl}+0.00005 \mathrm{~N} \mathrm{HCl}$ & 41 \\
\hline 12- gram green spotted sun-fish. & $0.25 \mathrm{~N} \mathrm{NaCl}$ & 48 \\
\hline 8- gram green spotted sun-fish.. & $0.25 \mathrm{~N} \mathrm{NaCl}+0.00005 \mathrm{~N} \mathrm{HCl}$ & 144 \\
\hline 3-gram green spotted sun-fish.. & $0.0001 \mathrm{~N} \mathrm{HCl}$ & 48 \\
\hline 3-gram green spotted sun-fish. & $0.0001 \mathrm{~N} \mathrm{HCl}+0.12 \mathrm{~N} \mathrm{NaCl}$ & $\begin{array}{l}\text { normal at end } \\
\text { of month }\end{array}$ \\
\hline 45-gram green spotted sun-fish.. & $\begin{array}{l}0.25 \mathrm{~N} \mathrm{NaCl}+\mathrm{KOH} \text { to make } \\
\text { just alk. }\end{array}$ & 14 \\
\hline
\end{tabular}

concentrations of $\mathrm{NaCl}$ when a trace of $\mathrm{HCl}$ is added. Also that fishes in toxic concentrations of $\mathrm{HCl}$ live longer when $\mathrm{NaCl}$ is present. Furthermore, $\mathrm{NaCl}$ is much more toxic in faintly alkaline solutions than it is in faintly acid solutions. All this agrees with Osterhout's conclusions as to the effect of alkalies and acids on permeability.

\section{Resistance to the salts of $\mathrm{Ca}$ and $\mathrm{Mg}$}

The only resistance experiments which have been carried on with these salts are some that were performed at Chicago. The experiments with $\mathrm{Ca}$ were performed in connection with the acclimatization experiments already discussed. In brief, it was found that the sun-fishes lived very well in $0.01 \mathrm{~N} \mathrm{CaCl}_{2}$, while the bull-heads did not live so well. Other experiments showed this same relation for the nitrate and sulphate but the latter salts were decidedly more toxic than the chloride and the sun-fishes did not live well in solutions of them. An interesting fact was noted in connection with the $\mathrm{CaCl}_{2}$ experiments. A medium sized ( 50 -gram) rock bass, after a week in $0.01 \mathrm{~N}$ solution, showed signs of degeneration of the rays of the tail fin. This degeneration continued until nothing but the blood-reddened stub of the tail was left. The other fins were not affected; the tail fin regenerated when the fish was returned to tap water. 
Day ('87, p. 203) states that in a certain lake in the British Isles, there is a race of tailless trout which some authors claim can be traced as due to the action of deleterious matter in the water. Day (loc. cit) also quotes J. Harvie-Brown as saying, about 1876, "that a contraction of the rays of the tail fins of the trout in the river Carron occurred, and was believed to be due to the continuous pollution of the water through the agency of paper mills." Upon looking up the composition of the waste from the paper mills (Griffin and Little '94, and Phelps '09) I find that among other substances calcium is always present in large quantities, both as the chloride and in other combinations. Therefore the phenomenon reported by Day was likely due to the presence of an excess of calcium in the water.

Marsh ('07) has shown that the waste from paper mills is very toxic to fishes. Calcium is not especially important, however, as the toxicity of the waste is probably due to the excess of acidity or alkalinity, and perhaps to other toxic substances.

\section{GENERAL DISCUSSION}

The experiments discussed in the preceding pages will be considered very briefly in one or two phases of their general bearing. From an ecological point of view they emphasize once more the ability of fishes to recognize and react to environmental factors in very small concentration. It should be pointed out, however, that the reactions of fishes to salts in solution are by no means so delicate as their reactions to acids and alkalies, i.e., to hydrogen and hydroxyl ions. As a matter of fact the reaction to salts is complicated by the acid factor in many cases, as, for instance, when the salt gives an acid solution, but more especially in the numerous instances where there exists an antagonism between the salt and the acid. Thus fishes may react differently to a given salt concentration in water which is strongly acid and water that is but faintly acid. The resistance experiments show, also, that fishes can live in the presence of an acid concentration which would ordinarily kill them, if the proper concentration of the right salts is present. The work of Osterhout ('15) and others, as well as data presented in this paper, 
indicates that the antagonism between the salts of calcium and magnesium is not nearly so marked as it is in the case of the salts of sodium and potassium. Since the former salts are by far the most common and plentiful in natural fresh waters, the importance of salts in nature in antagonising introduced acids is less than it would be were the salts of sodium and potassium plentiful. The problem is one which will furnish material for some very interesting ecological investigation.

The importance of small amounts of ammonia in natural waters has been pointed out in the discussion of these salts. The effects of starvation upon fish metabolism and reaction will be further discussed in another paper. There is an interesting possibility brought out by the acclimatization and other. data, especially those pertaining to the importance of acids, that will be discussed here. This possibility relates to the movements of organisms in general but the present discussion will be limited to the very interesting migrations of the anadromous fishes.

The stimulus that causes anadromous fishes to spend part of their life cycle in fresh and part in salt water has long been a matter for speculation. Such stimulus must be related to the rhythmical metabolism of the animal, for it brings the fishes into the sea or fresh water at certain definite stages in the life cycle. The state of the metabolism of these fishes while they are in the fresh water, must differ very decidedly from that during the period of the life cycle which they spend in the ocean, for these two environments differ in two very important particulars, namely, the fresh water has a low specific gravity and is consistently acid in reaction, while the sea water has a relatively high specific gravity and is consistently alkaline. Also the reactions of the fishes are markedly different. In the fresh water they are positive to current, and, in a gradient, select water that is just on the acid side of neutrality and of lower density than that of the sea. Salt water fishes, on the other hand, are probably negative to a fresh water current, select water on the alkaline side of neutrality and reject water of low specific gravity for that of higher (Shelford and Powers '15). The reactions of the fishes in fresh water, 
therefore, are the reverse of those in sea-water with regard to these three factors, and in the normal life cycle of such anadromous fishes as the salmon, this reversal in reaction must occur at least twice, once when the fishes leave the fresh water streams for the ocean, and again when they return. With species of salmon that breed more than once, the reversal must occur more often.

There are two general complexes of factors to be considered in an attempted explanation of the reactions of the anadromous fishes, namely, the fish and the environment. Both are made up of physico-chemical factors which are measurable, and to a large degree quantitatively. Of the two complexes, that of the living organism is least understood and perhaps, because it is much more variable and changing than the environmental complex, which, especially in the case of the sea-water, varies hardly at all. For the fishes to live normally in the environment there must exist between the two complexes a more or less complete equilibrium. A disturbance of this equilibrium resulting from a change in either of the complexes, will, if great enough or long enough continued, result in the death of the fishes unless by their reactions they seek out another environment which allows their physiological processes to proceed normally. It should be emphasized that the only mode of readjustment is through the proper reaction, either physiological or motile upon the part of the fishes, since the environment is much the more stable complex, and there is a great deal of evidence to show that of the two possible reactions upon the part of the living organism, the motile reaction is much more likely to occur than the physiological readjustment, i.e., acclimatization. The data presented in this paper and the one preceding (Wells '15a) as well as that by Shelford and Allee ('13) and Shelford and Powers (15) show that fishes will react to environmental factors in a way that will tend to remove them from detrimental conditions, long before the adjustment becomes a matter of life and death. Thus we find the salmon leaving the fresh water for the ocean, when, as will be pointed out later, it has been shown (Day '87) that remaining in the fresh water for the entire life cycle would not 
result fatally either to the individual or to the species. The mechanism, therefore, which is working to preserve the life of the organism is so delicate that it produces beneficial reactions upon the part of the animal far in advance of life and death complications. The working of this mechanism is undoubtedly closely correlated with quantitative and perhaps qualitative changes in metabolism. These changes in metabolism will have a direct relation to the amount of $\mathrm{CO}_{2}$ given off by the organism.

It has been shown that a slight increase in the carbon dioxide content of an animal's blood results in a marked increase in the general irritability, and this increase in irritability would alone result in an increase in the range and vigor of the movements made by the organism. Thus no factor other than increased metabolism need be hypothecated to account for the stimulus which starts the breeding migration of so many animals. The directive factors which result in the animal's coming into special conditions for the breeding activities are another matter. These can be none other than the factors, physical and chemical, which are present in the environment. In the general metabolism of fishes, the stage of development of the sex organs plays an important rôle, and it is very probable that the state of metabolism in these organs furnishes the initial stimulus which causes the animals to start upon the breeding migrations at a given period of the life cycle. Treadwell ('15) points out that the eggs of the Atlantic palola give off an increasing amount of $\mathrm{CO}_{2}$ as the swarming season approaches, and concludes that this indicates that there is probably an internal stimulus which is important in producing the swarm. There can be little doubt but that such internal stimulus is acting; the important fact, however, is that it has been shown that such internal changes in the physiological state of the animal may result in very marked changes in the animal's reactions to environmental factors. Allee ('12) has. shown that, in isopods, a high rate of metabolism is correlated with a high percent of positive responses to current and that a lowering of the metabolic rate in the animals will diminish and even reverse the rheotactic reaction. 
If we consider the different reactions of the salmon to current, acidity, and density, at different stages in the life cycle, beginning with the hatching of the egg we may proceed as follows. It is a well established fact (Loeb '13) that in the fertilized egg and newly hatched fry, the rate of oxidation is high, and it seems to be clear (Wells '13) that from this time on, up to sexual maturity the rate runs down. That is, the rate varies inversely with the age of the fish. Salmon eggs hatched in fresh water must develop into fry which are able to live in slightly acid water, of relatively low density, and the fishes must also be positive to current or they will be swept from the stream. This we find is true and thus ability to live in fresh water is correlated at this time with a high metabolic rate. As time goes by, however, the rate of reaction becomes gradually lower until we find the fishes either becoming actively negative, or at least indifferent to current, and they are swept or swim into the ocean. They now live for some time in the alkaline water of the ocean, and are able to withstand its much higher density. The equilibrium between the environment and the organism is again disturbed after a time, however, and we find the fishes once more selecting the fresh water at another period of high metabolic rate, i.e., with the maturing of the sex glands. From this it would seem entirely possible that fishes which are normally fresh water forms might be temporarily transformed into salt water forms by regulating, that is lowering, the rate of metabolism.

With regard to the selection of the water of greater or lesser density, the data presented in this paper offer an interesting possibility. It has been shown that fresh water fishes whose metabolic rate has been lowered by starvation, will select a notably higher concentration of $\mathrm{CaCl}_{2}$ in the gradient than will normal fishes. Also older fishes select a higher concentration than do younger ones. Thus a lowering of the metabolism causes the fishes to choose a medium with higher specific gravity than that normally chosen. It will be remembered furthermore that a stay of a little less than a week in $0.01 \mathrm{~N} \mathrm{CaCl}_{2}$ solution caused a fish that was normally negative to this concentration in a gradient, to become positive. Upon being returned to the tap 
water the reaction was again reversed and the fish became negative once more.

Acclimatization of fishes to salts must certainly be concerned with internal adjustments, for Sumner ('07) has shown that the specific gravity of fishes' blood is altered when they are changed from fresh to sea-water, and vice versa. An alteration in the density of the blood seems then to result in a reversal in the reactions of the organism to density in the environment. Green ('04) has shown that changes in the specific gravity of the blood of the salmon occur at the time the fishes are entering the fresh water; the blood gradually acquires a density that averages 17.6 per cent less than that of salmon in sea-water (l.c., p. 454). Jones ('87) has proved that age, exercise, sexual maturity, pregnancy, food, etc., have a measurable influence upon the density of the blood of man, and Sumner ('07) states that there are seasonable differences displayed by fishes, in the osmotic phenomena through their gills. It may be that the specific gravity of the blood of anadromous fishes at different stages in the life cycle, can be used as an index to the physiological changes that are going on in the organism. Also the effect upon the organism of a higher $\mathrm{CO}_{2}$ production within the tissues must vary with the density of the blood and would probably be more marked when the blood is less dense.

An investigation of the changes in the density of the blood of the salmon could perhaps best be begun with the fry in the fresh water streams. As the fishes remain for 2 years or even 3 in the fresh water before leaving for the ocean, a thorough study of the relative densities of the blood and the fresh water could be made in this period. That the instinct which causes these fishes finally to reject the fresh water for that of the sea, is backed by some very strong stimulus is indicated by data given by Day ('87). Day speaks of an experiment which was carried on by Maitland in 1880. Eggs of salmon were hatched in fresh water, and the young salmon were placed in ponds shut off from the sea. These fishes ate well and grew vigorously until they were about $2 \frac{1}{2}$ years old. At this stage in the life history, the individuals are known as 'smolts' and it is at the smolt stage that they 
leave the fresh water. In October, 1883, one of the fishes jumped out of the pond onto the bank. By the end of November, several had jumped out onto the bank and died there (they usually jumped during the night or early morning). In the following May, 16 of the fishes were found dead on the bank. Then the following October (1884) they commenced constantly jumping out of the pond and meeting with fatal injuries. It was observed that the fishes did not feed at this latter date; this failure to take food is characteristic of salmon entering fresh water to breed.

Examination of the fishes which had jumped out of the pond showed that all were approaching maturity and in the later cases, the eggs and sperm were ripe. An attempt was made to fertilize the eggs with the sperm, with good success. Day states that this second generation was normal and vigorous up to 20 months and concluded that it was definitely proved that a sojourn in salt water is not necessarily for the development of the sexual products. If this is true, the migration of the salmon into the salt water, and back again, is all the more curious. There would be advantages and disadvantages to such behavior but the above data prove that the fishes are reacting to the environment in a way that is not immediately essential though the stimulus seems to be a very strong one. A study of the behavior of these fishes in salt, acid and alkali gradients at different stages in their life history, would undoubtedly prove very suggestive and such a study correlated with physiological investigations of the fishes at similar stages will without doubt solve the question of the movements of anadromous fishes.

\section{GENERAL CONCLUSIONS}

1. Fresh water fishes recognize and react to the presence of salts in solution. The reaction is one which tends to bring them into their optimum salt concentration.

2. Fresh water fishes (and probably marine fishes also, Shelford and Powers '15) are not as sensitive to salt ions as they are 
to hydrogen and hydroxyl ions. The reactions to either the ions of salts or acids are complicated by the presence of the ions of the other.

3. Fresh water fishes react to combinations of antagonistic salts or to an antagonistic salt and acid, in a way that tends to bring them into a region of optimum stimulation. The phenomena of antagonism are thus indicated by the behavior as well as the resistance of organisms.

4. Starvation causes certain fishes (e.g., Ambloplites rupestris, rock bass) to select higher concentrations of salt than those normally selected. Other fishes (Ameiurus melas, bull-head) when starved, select lower concentrations than normally. Overfeeding causes bull-heads to select higher concentrations, than those normally chosen.

5. Rock bass and bull-heads which are normally negative to $\mathrm{CaCl}_{2} 0.01 \mathrm{~N}$ solution, become positive after being kept in this concentration for about a week. They become negative again when returned to tap water for 24 hours.

6. The migrations of anadromous fishes are probably correlated with rhythmic changes in metabolism. These alterations in metabolic activity are largely the result of internal changes such as occur with the ripening of the sexual products.

I am indebted to Prof. V. E. Shelford for proposing this problem and for many suggestions during the work. I am also under obligation to Mr. Karl A. Clark of the Chemistry Department for helpful criticisms and for the loan of apparatus. 


\section{BIBLIOGRAPHY}

ALLEE, W. C. 1912 An experimental analysis of the relation between physiological states and rheotaxis in Isopoda. Jour. Exp. Zoöl., vol. 13, pp. 269-344.

1913 Further studies in physiological states and rheotaxis in Isopoda. Ibid., vol. 15, pp. 257-295.

Atrees, W. C. and Tashiro, Shiro 1914 Some relations between rheotaxis and the rate of carbon dioxide production in Isopoda. Jour. An. Behav., vol. 4, no. 3, pp. 202-214.

(HILD, C. M. 1913 Studies on the dynamics of morphogenesis and inheritance in experimental reproduction. $V$. The relation between resistance to depressing agents and rate of metabolism in Planaria dorotocephala and its value as a method of investigation. Jour. Exp. Zoöl., vol. 14, pp. 153-206.

Dar, Francls 1887 British and Irish Salmonidae. Williams and Norgate, 14 Henrietta St., Covent Garden, London.

(irevas, C. W. 1904 Physiological studies of the Chinook salmon, Bull. U. S. Bur. Fisheries, vol. 24, pp. 429-456.

Griffix, R. B., And Littel, A. D. 1894 The chemistry of paper making. Howard Lockwood and Co., New York.

JoNes, E. Lloyd 1887 On the variations in the specific gravity of the blood in health. Jour. Physiol., vol. 8, p. 1.

IILLIE, R. S. 1910 The physiology of cell division. II. The action of isotonic solutions of neutral salts on unfertilized eggs of Asterias and Arbacia. Am. Jour. Phys., vol. 26.

1911 The physiology of cell division. III. The action of calcium salts in preventing the initiation of cell division in unfertilized eggs, through isotonic solutions of sodium salts. Am. Jour. Phys., vol. 27, p. 289.

LofB, JaCGues 1899 Ueber die Aehnlichkeit der Flüssigkeitsresorption in Muskeln und in Seifen. Pflüger's Archiv, Bd. 75, p. 303.

1912 Untersuchungen uber Permeabilität und antagonistiche Elektrolytwirkung nach einer neucn Methode. Biochemische Zeitschrift, 47, p. 127.

Lovi, J., and Wasteneys, Hardolph 1911 Die Entgiftung von Säuren durch Salze. Biochemische Zeitschrift, Bd. 33, p. 489.

1912 Weitere Versuche über die Entgiftung von Säuren durch Salze. Biochemische Zeitschrift, Bd. 39, p. 167.

MacCallum, J. B. 1905 On the diuretic action of certain haemolytics and the action of calcium and magnesium in suppressing the haemolysis. Univ. of Calif. Publ. 1-2, p. 93. 
Marsh, M. C. 1907 The effect of some industrial wastes on fishes. House Documents, vol. 64. Water Supply and Irrigation Papers. 190607, p. 337.

Mathews, A. P. 1907 The cause of the pharmaologicol action of ammonium salts. Am. Jour. Phys., vol. 18, p. 58.

Meltzer, S. J., AND AUer, J. 1908 Rigor mortis and the influence of calcium and magnesium salts upon its development. Jour. Exp. Med., vol. 10 , p. 45.

Osterhout, W. J. V. 1914 Antagonism between acids and salts. Jour. Biol. Chem., vol. 19 , p. 517.

1915 On the nature of antagonism. Science, vol. 41, p. 255.

Phelps, E. B. 1909 The pollution of streams by sulphite pulp waste. A study of possible remedies. U. S. Geol. Surv. Water Supply Paper 226.

Ringer, S. 1886 Further experiments regarding the influence of small quantities of lime, potassium and other salts on muscular tissue. Jour. Physiol., vol. 7, p. 291.

Shelford, V. E., ANd Allee, W. C. 1914 Rapid modification of behavior of fishes by contact with modified water. Jour. An. Behav., vol. 4, no. 1, pp. 1-30.

Shelford, V. E., AND Powers, E. B. 1915 An experimental study of the movements of herring and other marine fishes. Biol. Bull., vol. 28, pp. 315-334.

StMNER, F. B. 1905 Further studies of the physical and chemical relations between fishes and their surrounding medium. Bull. Bur. Fisheries, vol. 25 , pp. 55-108.

1907 Further studies of the physical and chemical relations between fishes and their surrounding medium. Am. Jour. Physiol., vol. 19, p. 61.

Wells, M. M. 1913 The resistance of fishes to different concentrations and combinations of carbon dioxide and oxygen. Biol. Bull., vol. 25, no. 6 .

1915 a Reactions and resistance of fishes in their natural environment, to acidity, alkalinity and neutrality. Biol. Bull., vol. 29, pp. 221-257. 